\title{
Food Safety Knowledge, Attitudes and Behavior of Street Food Vendors and Consumers in Dhaka City
}

\author{
Sumaiya Mamun ${ }^{1}$, Sabiha Alam¹, Mohammad Abduz Zaher ${ }^{1}$, A.K. Obidul Huq² \\ ${ }^{1}$ Institute of Nutrition and Food Science, University of Dhaka. ${ }^{2}$ Mawlana Bhashani Science and Technology University, Santosh, Tangail-1902, Bangladesh.
}

\begin{abstract}
Food safety knowledge, attitudes, and street food suppliers and consumer behaviors of the capital city Dhaka were investigated. A cross-sectional study was conducted using questionnaires based on previous studies. Three main areas addressed in the surveys and statistical analysis are; 1) statistical data including gender, age, education, income, food safety training, and specific elements related to the work experience of suppliers, 2) knowledge of food safety such as the awareness of consumers and suppliers concerning pathogenic microbes that cause food poisoning, food and personal hygiene, proper cleaning procedures and high-risk groups, and 3) list of food handling attitude and behavior of subjects. Results showed food safety knowledge of street vendors in the High-tech Industries Development Zone was the lowest, where education levels are generally relatively low. Food safety attitudes of the youngest consumers were significantly better than those of older age groups. Street vendors were relatively poor in carrying out safe food handling, with only $\mathbf{2 7 . 6 \%}$ using or being fully equipped with hand-washing facilities, although more than $\mathbf{5 0 \%}$ of vendors were not wearing clean and tidy clothes and masks. Steps should be taken to improve street food stall operating conditions and facilities, including access of potable water, providing clean protected structures, and efficient waste collection and disposal systems that can promote the plans and strategies to improve street food safety of Dhaka city and Bangladesh as a whole.
\end{abstract}

Keywords: Street food, Food safety knowledge, attitude, behavior, Vendors, Consumers

\section{Introduction}

Street food refers to a wide variety of ready-to-eat (RTE) foods which are sold beside the busy streets and public places ${ }^{1,2}$. In many developing countries the street food industry is booming along with the expeditious population growth and urbanization ${ }^{3-5}$. In many lowincome countries, the uneducated, unemployed urban population are having an employment opportunities based on this street food business ${ }^{6,7}$. Street foods are widely consumed by low earning people because these are easily accessible and cheap ${ }^{8}$. Most vendors are poor, uneducated, untrained and unlicensed for their business 9,10 The potential causes of microbial contamination includes the unhygienic environment of foods preparation and storage and manhandling of food ${ }^{11,12}$. Commonly detected foodborne pathogens in street foods are E. coli, Bacillus cereus, Clostridium perfringens, Staphylococcus aureus and Salmonella spp ${ }^{13-15}$. Consumers of street food often suffer from foodborne diseases like diarrhea, cholera, typhoid fever and food poisoning ${ }^{16,17}$. Contaminated street food has also caused foodborne epidemics ${ }^{18-21}$.

In developing countries millions of low earning people consider street food as a convenient diet for them ${ }^{22}, 23$. Approximately 2.5 billion people eat street food everyday, which supports the livelihood of those low earning people. Not only that, it has an enormous contribution to the economy ${ }^{24}$.

Street food safety remains a major concern in developing countries $^{25}$. Bangladeshi food culture has a long history of street food. It has become somewhat of an identity of Bangladeshi culture. Many big cities as well as small towns and villages provide street food to the locals and tourists. Therefore, street food safety has become a major food safety concern due to poor food hygiene and handling conditions ${ }^{26}$. Most street food vendors are comparatively uneducated and often lack proper knowledge and have poor regulatory behaviour towards correcting oversight ${ }^{27}$.

This study has undertaken to find the food safety status of street food in Capital City of Bangladesh (Dhaka), for which a suitable questionnaire was constructed to assess food safety knowledge, attitudes, and behaviors of street food vendors and consumers.

\section{Materials and Methods}

This is a cross-sectional study conducted on 247 consumers and 90 street vending stalls. Structured written questionnaires were used to assess food safety knowledge and attitudes of vendors. A structured questionnaire was used to record demographic information. This section gathered details regarding sex, age, educational level, income, and training in food safety, with a specific element relating to work experience for vendors.

\section{Food safety knowledge}

This section assessed consumer and vendor awareness of food poisoning pathogens, food and personal hygiene, high risk groups, proper cleaning, etc. There were 18 questions with three possible answers: "yes", "no" and "do not know". Each "yes" answer 
assigned one point, rest assigned 0 points. Hence, a maximum of 18 questions were included in this section. The top score for each question was of 100 points, where a score $<50$ was regarded for a low level of knowledge in food safety, 50-75 regarded as a satisfactory level, and more than 75 was regarded as good. These questions evaluated food safety attitudes, including food preference, handling, and personal hygiene. There were 16 questions with three possible answers: 'yes', 'no', or 'do not know', with one point for each 'yes' and 0 points for the rest.

To ensure appropriate consumers and street vendors were included in the survey, researchers focused on schools, markets, parks, residential communities, and people-intensive streets in the four districts. All respondents participated voluntarily, were over 15 years of age, and were selected randomly. After interviewing 100 respondents, the questionnaire was revised and the new edition used to interview a further 247 respondents for final analyses of consumers.

\section{Statistical analysis}

The data obtained from the questionnaires and observation checklists were analyzed using SPSS version 21.0, and then exported to Microsoft Excel to calculate the various scores. We used the following analysis categories:

- Age groups were 18-25, 26-35, 36-45 and $>45$

- Scores were aggregated into ranges of $<50,50-75$, and $>$ 75 points;

- Consumer income cut-offs were grouped at 2000, 4000, and $>6000 \mathrm{Tk} / \mathrm{month}$;

Descriptive analyses used mean, standard deviation, maxima, and minima for each age category. Scores were assessed according to age, education, location, income and sex. The two-sample ttest was used to compare data sets in terms of sex and training status. Comparisons of more than two groups were conducted by fixed effects analysis of variance. Data and residual normality were first tested using quantile-quantile plots or the KolmogorovSmirnov test, and variance equality was checked using the modified Levene test. Non-normally distributed data sets and those with sample size less than 30 were analyzed using the nonparametric Wilcoxon rank sum test for two category cases, i.e., sex (male or female), food safety training status (trained or untrained) etc., and the Kruskal-Wallis rank sum test was used when there were more than two categories, i.e., age groups, income level, work experience, location (district), and educational level. Statistically significant differences were based on $95 \%$ confidence limits, i.e., $\pm=0.05$ or $\mathrm{p}<0.05$.

\section{Results}

In the present investigation, the capital city Dhaka was selected as the research object for the assessment of food safety knowledge, attitudes, and street food suppliers and consumer behaviors. A cross-sectional study was conducted using questionnaires based on previous studies. The food safety knowledge and attitude questionnaire conformed to the national conditions in Bangladesh. Three main areas were addressed in the surveys and statistical analysis that are: 1) statistical data where gender, age, education, income, food safety training, and specific elements related to the work experience of suppliers included. (2) knowledge of food safety that included the awareness of consumers and suppliers concerning food poisoning by pathogenic microbes, personal hygiene, proper cleaning procedures and high-risk groups and (3) list of food handling attitude and behavior of subjects.

Table 1 summarizes socio-demographic characteristics of the 247 respondents (Consumers). Consumer age ranged from 18 to 72 years (mean, $30.95 \pm 11.3$ years), with $85.64 \%$ between 18 and 45 years of age, and $>44.5 \%$ was $18-25$ years of age; whereas vendor age was somewhat more restricted: $20-55$ years of age. Consumers' education level showed that $23.4 \%$ had attained high school, but more than half $(53.8 \%)$ had university, or postgraduate level education. Consumers' income showed that $70 \%$ of them earned less than $4000 \mathrm{Taka} / \mathrm{month}$.

Table 1: Socio-demographic characteristics of respondents (consumers)

\begin{tabular}{lll}
\hline Characteristic & & Count \\
\hline Gender & Female & $123(49.8 \%)$ \\
& Male Age (year) & $124(50.2 \%)$ \\
Age (Years) & $18-25$ & $110(44.5 \%)$ \\
& $26-35$ & $64(25.9 \%)$ \\
& $36-45$ & $40(16.1 \%)$ \\
& $>45$ & $33(13.4 \%)$ \\
Education & Illiterate & $10(4.04 \%)$ \\
& Primary school & $17(6.8 \%)$ \\
& Middle school & $28(11.3 \%)$ \\
& High school & $58(23.4 \%)$ \\
& University & $133(53.8 \%)$ \\
Income (Tk./month) & $<2000$ & $102(41.2 \%)$ \\
& $2001-4000$ & $70(28.3 \%)$ \\
& $4001-6000$ & $45(18.2 \%)$ \\
& $>6000$ & $17(6.8 \%)$ \\
\hline
\end{tabular}

Table 2 shows food safety knowledge of street food consumers in Dhaka city. However, many consumers $(48,20 \%$,) had poor food safety knowledge (score $<50$ ). There was no significant difference in food safety knowledge with regards to sex $(\mathrm{p}=$ $0.322)$, educational level $(p=0.621)$, or monthly income $(p=$ 0.540 ). Mean consumer education $=66$ points, and mean food training $=56$ points. Thus, consumers need to continue to improve their food safety knowledge.

Generally, younger consumers with higher education had higher levels of food safety knowledge, whereas older consumers had less knowledge, where the consumers aged 26-35 years had the highest level of knowledge and those aged 56-60 years had the lowest. However, there were significant differences between those in the groups aged $18-25$ and $46-55$ years $(\mathrm{p}=0.04), 26-35$ and $46-55$ years $(\mathrm{p}<0.05)$, and $26-35$ and $56-60$ years $(\mathrm{p}=0.02)$.

Table 3 shows consumers' attitudes toward food safety. Consumers also had an adequate understanding of food safety, where more than $70 \%$ had scores $>50$ points and $18 \%$ had scores 
Food Safety Knowledge, Attitudes and Behavior of Street Food

Table 2. Food safety knowledge of street food consumers in Dhaka city

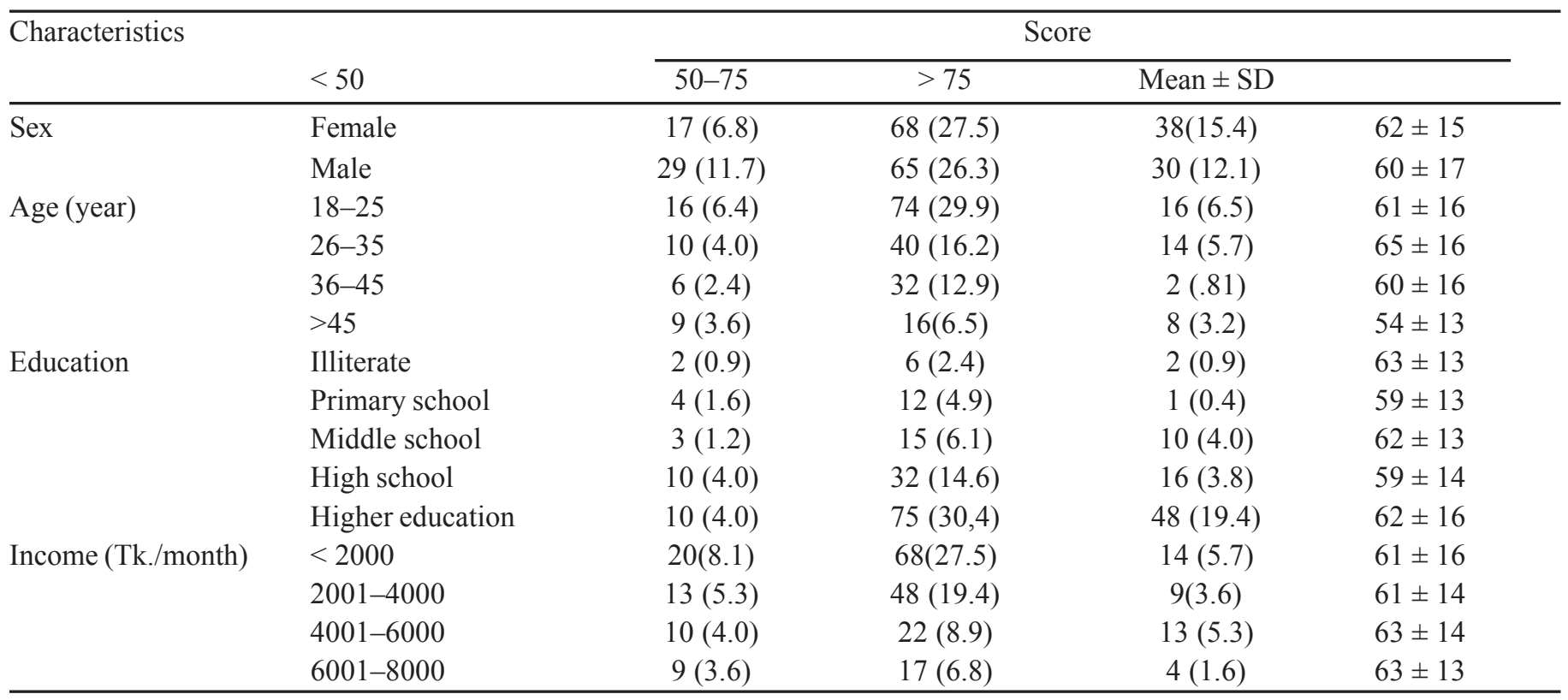

Table 3. Consumer attitudes toward food safety

\begin{tabular}{|c|c|c|c|c|c|}
\hline & \multirow[t]{2}{*}{ Characteristic } & \multicolumn{4}{|c|}{ Score } \\
\hline & & $<50$ & $50-75$ & $>75$ & Mean $\pm \mathrm{SD}$ \\
\hline Gender & Female & $25(10.1)$ & $81(32.8)$ & $17(6.9)$ & $62 \pm 15$ \\
\hline \multirow[t]{2}{*}{ Age (year):(n=52) } & $18-25$ & $26(10.5)$ & 64 (25.9) & $20(8.1)$ & $61 \pm 15$ \\
\hline & $26-35$ & $10(4.0)$ & $32(12.9)$ & $22(8.9)$ & $63 \pm 15$ \\
\hline \multirow[t]{4}{*}{ Education $(n=35)$} & Illiterate & $4(1.6)$ & $3(1.2)$ & $3(1.2)$ & $63 \pm 15$ \\
\hline & Primary school & $3(1.2)$ & $11(4.4)$ & $1(0.8)$ & $57 \pm 15$ \\
\hline & Middle school & $4(1.6)$ & $15(6.1)$ & $9(3.6)$ & $63 \pm 15$ \\
\hline & High school & $6(2.4)$ & $40(16.2)$ & $12(4.8)$ & $63 \pm 15$ \\
\hline & $6001-8000$ & $2(1.7)$ & $15(6.1)$ & $10(4.0)$ & $57 \pm 15$ \\
\hline
\end{tabular}

$>75$ points. Table 3 shows that increased education level significantly increased the proportion of consumers with score $>$ 50 points. Regarding the financial status, we can see that an income of 4001 to $6000 \mathrm{Tk}$ for the consumer showed the highest was $(6.8 \%)$ on food safety and safety attitude.

\section{Discussion}

The main purpose of this study was to assess food safety knowledge and attitudes of street food consumers and vendors, and food handling behavior of food vendors in Dhaka city, Bangladesh. To our knowledge, there are very few studies to evaluate and report these important aspects of street food safety in Dhaka city. The pure food ordinance of Bangladesh was introduced 1959, and the food safety law in 2013, with stricter food safety terms and further conditions adopted in 2017. Most of the aforementioned concerns, and others discussed in this paper, are addressed in these regulations. However, in the present study we have found that the knowledge, attitudes, and behavior of the food handler had no change. Poor educational level and negligence could be a major factor here. Recommendation from this study is given below:

- There should be extensive training for street food vendors and consumers to improve the safety of street food.

- More implications of policies and measures are important 
to improve the food safety knowledge, attitudes, and behavior of the consumers and vendors.

- Possible measures should be taken to improve food handling conditions and facilities, e.g., access to clean water, providing clean $\&$ protected structures, and efficient waste collection and disposal systems.

\section{References}

1. Simopoulos AP, Bhat RV. 2000. Profile of street foods sold in Asian countries. In: Simopoulos AP, Bhat RV (eds). Street Foods. Rome: Karger. pp. 53"99.

2. Jouve JL, Aagaard-Hansen J, Aidara-Kane A. 2010. Food safety: equity and social determinants. In: Erik Blas, Anand SK (eds). Equity, social determinants and public health programmes. WHO. pp. 95"114.

3. Maxwell D, Levin C, Armar-Klemesu M, Ruel M, Morris S, Ahiadeke C. 2000. Urban

livelihoods and food and nutrition security in Greater Accra, Ghana: International Food Policy Research Institute Washington, DC. pp.1-156.

4. Ismail SA. 2006. Microbiological quality of hawawshy consumed in Ismailia, Egypt. J. Food Safety. 26(4): 251-263.

5. Bhowmik SK. 2005. Street vendors in Asia: a review. Economic and Political Weekly. pp. 2256-2264.

6. Latham M. Human nutrition in tropical Africa. 1965. In: Latham M, Michael C (eds). A textbook for health workers with special reference to community health problems in East Africa. Food Agri. Org. pp. 123148.

7. Barro N, Bello A, Savadogo A, Ouattara C, IIboudo A, Traore A. 2006. Hygienic status assessment of dish washing waters, utensils, hands and pieces of money from street food processing sites in Ouagadougou (Burkina Faso). African J. of Biotech. 5(11): 1107-1112.

8. Tambekar D, Jaiswal V, Dhanorkar D, Gulhane P, Dudhane M. 2008. Identification of

microbiological hazards and safety of ready-to-eat food vendee in streets of Amravati city. India. J. Appl Biosci. 7: 195-201.

9. Muinde O, Kuria E. 2005. Hygienic and sanitary practices of vendors of street foods in Nairobi,Kenya. Agri. and Nutri. Develop. (AJFAND). 5(1): $1-13$.

10. Ekanem EO. 1998. The street food trade in Africa: safety and socioenvironmental issues. Food Control. 9(4): 211-215.

11. Feglo P, Sakyi K. 2012. Bacterial contamination of street vending food in Kumasi, Ghana. J Medi. Biomed. Sci. 1(1): 1-8.

12. Mamun MA, Rahman SMM, Turin TC. 2013. Microbiological quality of selected street food items vended by school-based street food vendors in Dhaka, Bangladesh. Int. J.Food Microbiol. 166(3): 413-418.
13. Rane S. 2011. Street vended food in developing world: hazard analyses. Indian J. Microbiol. 51(1): 100-106.

14. Mosupye FM, von Holy A. 1999. Microbiological quality and safety of ready-to-eat street-vended foods in Johannesburg, South Africa. J. Food Protec. 62(11): 1278-1284.

15. Muleta D, Ashenafi M. 2001. Salmonella, Shigella and growth potential of other food-borne pathogens in Ethiopian street vended foods. East African Med. J. 78(11): 576-580.

16. Cliver DO, Potter M, Riemann HP. 2011. Foodborne infections: Bacterial. In: Morris JG,

Potter M Jr (eds). Foodborne infections and intoxications. London: Academic Press. pp.66-78.

17. Vollaard AM, Ali S, van Asten HA, Widjaja S, Visser LG, Surjadi C et al. 2004. Risk

factors for typhoid and paratyphoid fever in Jakarta, Indonesia. JAMA. 291(21): 2607-2615.

18. Mahale DP, Khade RG, Vaidya VK. 2008. Microbiological analysis of street vended fruit juices from Mumbai city, India Int. J. Food Safety. 10: $31-34$.

19. Anandhi N, Janani, Krishnaveni N. 2015. Microbiological quality of selected street vended foods in Coimbatore, India. African J. Microbiol. Res. 9(11):757-62.

20. Al MM, Rahman SM, Turin TC. 2013. Knowledge and awareness of children's food safety among school-based street food vendors in Dhaka. Bangladesh Foodborne. Patho. Dis. 10(4): 323-30.

21. Karasavvidou E. 2005. Hygienic and sanitary practices of vendors of street foods in Nairobi. Kenya African J. Food Agric. Nutr. Dev. 1: 64950 .

22. Samapundo S, Thanh TNC, Xhaferi R, Devlieghere F. 2016. Food safety knowledge, attitudes and practices of street food vendors and consumers in Ho Chi Minh City, Vietnam. Food Control. 70:79-89.

23. Lues JFR, Mpeli RR, Venter P, Theron MM. 2006. Assessing food safety and associated food handling practices in street food vending. Int. J. Environ. Health Res. 6:319-28.

24. Ekanem EO. 1998. The street food trade in Africa: safety and socioenvironmental issues. Food Control. 9: 211-5.

25. Aluko OO, Ojeremi TT, Olakele DA, Ajidagba EB. 2014. Evaluation of food safety and sanitary practices among food vendors at car parks in Ile Ife, southwestern Nigeria. Food Control. 40: 165-71.

26. Hanashiro A, Morita M, Matté GR, Matté MH, Torres EAFS. 2005. Microbiological quality of selected street foods from a restricted area of São Paulo city. Brazil. Food Control. 16(5): 439-44.

27. Guven K, Mutlu MB, Gulbandilar A, Cakir P. 2010. Occurrence and characterization of Staphylococcus aureus isolated from meat and dairy products in Turkey. J. Food Safety. 30: 196-212. 